\title{
Erratum to: The crystal structure of Ac-AChBP in complex with $\alpha$-conotoxin LvIA reveals the mechanism of its selectivity towards different nAChR subtypes
}

\author{
Manyu $\mathrm{Xu}^{1}$, Xiaopeng $\mathrm{Zhu}^{2}$, Jinfang $\mathrm{Yu}^{1}$, Jinpeng $\mathrm{Yu}^{2}$, Sulan $\mathrm{Luo}^{2 \bowtie}, \mathrm{Xinquan}_{\mathrm{Wang}}{ }^{1 凶}$ \\ ${ }^{1}$ The Ministry of Education Key Laboratory of Protein Science, School of Life Sciences, Beijing Advanced Innovation Center \\ for Structural Biology, Collaborative Innovation Center for Biotherapy, Tsinghua University, Beijing 100084, China \\ ${ }^{2}$ Key Laboratory of Tropical Biological Resources, Ministry of Education, Key Lab for Marine Drugs of Haikou, Hainan \\ University, Haikou 570228, China \\ \Correspondence: luosulan2003@163.com (S. Luo), xinquanwang@mail.tsinghua.edu.cn (X.Wang)
}

ERRATUM TO: PROTEIN CELL (2017) 8(9):

$$
\text { 675-685 }
$$

DOI 10.1007/S13238-017-0426-2

In the original publication of the article the keywords are incorrectly online published. The correct keywords should read as " $\alpha$-conotoxin, nicotinc acetylcholine receptor, acetylcholine binding protein, X-ray crystallography".

\section{OPEN ACCESS}

This article is distributed under the terms of the Creative Commons Attribution 4.0 International License (http://creativecommons.org/ licenses/by/4.0/), which permits unrestricted use, distribution, and reproduction in any medium, provided you give appropriate credit to the original author(s) and the source, provide a link to the Creative Commons license, and indicate if changes were made. 